\title{
What universities do about tobacco industry research funding
}

\author{
Raoul A Walsh, Rob W Sanson-Fisher
}

\begin{abstract}
Objective-To investigate the current policies and practices of Australian institutions of higher education in relation to tobacco industry research funding.

Design-Descriptive study using institutional questionnaire and tobacco industry reports.

Subjects -45 institutions of higher education in Australia.

Results $-98 \%$ response rate from eligible institutions. $30 \%$ of institutions accepted tobacco industry research funds in 1991 or $1992.71 \%$ could not recall formal discussions ever occurring about the ethics of accepting tobacco industry funds. Although only two (5\%) institutions indicated they had institution-wide written policies which precluded acceptance of research funds from all tobacco industry sources, $10(24 \%)$ reported they did not circulate material promoting these funds. Seven out of $\mathbf{1 0}$ medical faculties had faculty-specific policies not to administer tobacco funds. Five $(12 \%)$ institutions anticipated that their policies about acceptance of tobacco industry funds would be modified within the next six months.
\end{abstract}

Conclusion - In the past decade, there has been a move by Australian institutions of higher education towards eschewing tobacco industry research funding. Nonetheless, the nexus between the tobacco industry and institutions of higher education remains strong. Concerted action by pro-health groups will be required to eliminate tobacco industry sponsorship of research.

(Tobacco Control 1994; 3: 308-315)

Faculty of Medicine and Health Sciences, Discipline of

Behavioural Science in Relation to Medicine, University of Newcastle,

Callaghan, Newcastle, NSW 2308 Australia R A Walsh

R W Sanson-Fisher

Correspondence to the Secretary, NSW Cancer Council Cancer Education Research Project, Locked Mail Bag 10, Wallsend, NSW 2287, Australia

\section{Introduction}

The ethics of accepting research funds from tobacco industry sources has been vigorously debated..$^{1-12}$ However, research funded by the tobacco industry continues to be published in the medical literature. ${ }^{13-15}$ Little is known about the current policies and practices of institutions of higher education in this area.

Currently, three organisations in Australia allocate research funds derived from tobacco industry sources. The Australian Tobacco Research Foundation (ATRF) is funded by the three major tobacco companies and provides support for postgraduate scholarships and medical projects "... which aim to elucidate the mechanism by which tobacco smoking is thought to be linked to human disease. However support will also be considered for projects which investigate other mechanisms which may be of relevance in these diseases ". ${ }^{16}$ A list provided by the ATRF of "some" research projects funded in 1991 and 1992 revealed that 11 out of 12 projects were in biomedical areas. The non-biomedical project involved the development and evaluation of smoking prevention strategies for adolescents. It is not known how many projects the ATRF funded in this period or how representative their list is. The total value of ATRF research grants and scholarships was approximately $\$ 650000$ in 1991 and $\$ 570000$ in 1992 (Ferguson JB, personal communication, 21 December 1993).

The Rothmans Foundation Education Division (RFED) awards fellowships for postdoctoral research to be undertaken within an Australian university or recognised research institution. ${ }^{17}$ Fellowships are awarded in a wide range of disciplines. Fellowships have never involved tobacco-related research and none has been awarded in a medical setting since 1983. The current stipend has an annual value of $\$ 39000$ plus an allowance of $\$ 11000$. The RFED does not release details of its budget. However, since 1985 no more than three awards have been made in each year. Funds available from the RFED would, therefore, not exceed approximately $\$ 150000$ per annum in 1993 prices.

Unlike the ATRF and the RFED, the Tobacco Research and Development Council (TRDC) is not controlled by the tobacco industry but operates under an act of parliament, the Primary Industries and Energy Research and Development Act 1989.18 The TRDC comprises a Chairperson, a government member and, as determined by the Minister for Primary Industries and Energy after consultation with industry organisations, six other members. Research funds come from a levy on tobacco growers and manufacturers plus a government contribution. All TRDC funding is directed towards the tobaccogrowing sector and most is concentrated at two specialised tobacco research centres. In the 1991-92 financial year, research and development payments totalled $\$ 1883780$. Table 1 
Table 1 Types of research funded by tobacco industry sources in Australian institutions of higher education in 1991 and 1992

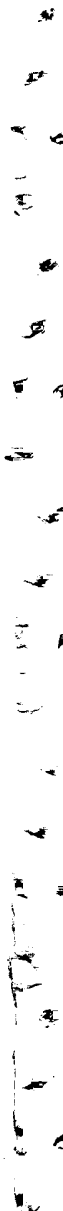

Australian Tobacco Research Foundation $(A T R F)^{1}$ :

- Inhibition of lung cancer development by antibodies to angiogenic growth factors

Role of lymphocytes in the pathogenesis of particleinduced pulmonary fibrosis

Glutathione S-transferase 1 deficiency and susceptibilit

to cancer

Brain monoamine oxidase activity and the effect of

smoking

Relationship between cigarette smoking, upper

gastrointestinal motor dysfunction and peptic ulce disease

The role of cigarette smoke in enhancing uptake of low

density lipoproteins by macrophages

Development, implementation and prospective evaluation of smoking prevention strategies for Australian adolescents

Sidestream smoke effects in active and passive smoking on the dissipation of catecholamines in the lung

The role of nicotine receptors in synaptic transmission in the hippocampus

Modulation of the nicotine acetylcholine receptor

- Mechanisms of action of nicotine on neurotransmission

- Fetal hypoxia and lung development

Rothmans Foundation Education Division (RFED):

- Mitosis and cell division in unicellular algae

- General relativity quantum gravity

Designs and finite geometries in information technology

Molecular biology of herpes viruses

Population genetics and reproductive ecology

Tobacco Research and Development Council (TRDC)

- Biology and control of black shank disease

${ }^{1}$ Incomplete list provided by ATRF

summarises what is known about the types of research funded in Australian institutions of higher education by tobacco industry sources in 1991 and 1992.

Arguments for and against accepting research funds from tobacco industry sources do not seem to hinge on the magnitude of the health risks caused by smoking. Members of the Scientific Advisory Committee of the ATRF have been unanimous in declaring their belief that smoking is an important causative factor in several major diseases. ${ }^{6}$ The vast majority of scientists funded by the Council for Tobacco Research (CTR), a US body formed by cigarette manufacturers, agreed that cigarette smoking is an addiction that causes a wide range of serious, often fatal, diseases. ${ }^{12}$

Proponents of tobacco industry research funding stress that resources for financing medical research are scant and that opportunities for productive research exist to investigate the mechanisms that link smoking and disease. ${ }^{4,6}$ However, the RFED and TRDC do not fund research of this type. In Britain, the industry-sponsored Health Promotion Research Trust also does not fund studies into the use and effects of tobacco. ${ }^{5}$ The list (table 1) supplied by the ATRF of the titles of some funded research projects indicates that most do not involve a focus on the health effects of tobacco. Similarly, only about one in six of CTR-funded research projects is in the health effects area. ${ }^{12}$

Secondly, it is argued that because the activities of the tobacco industry are legal and tobacco use is relatively common practice, it is desirable to use some of the profits made available by the industry to undertake research which is for the benefit of humanity. ${ }^{2,4,6}$ Thirdly, emphasis is placed on the independent approach adopted by the Scientific Ad- visory Committee of the ATRF. ${ }^{4.6}$ The granting mechanism consists of open advertisements for applications, the review of submissions by the Scientific Advisory Committee, reports by outside experts, and where necessary, interviews. No individual or research group is canvassed to apply, and research workers have no direct contact with the industry. ${ }^{6}$ While members of the tobacco industry see all applications, it has been stated that the industry has not attempted - and indeed has no power - to influence decisions on research projects, or to determine the direction of research or to influence the publication or results. ${ }^{6}$ It is also argued that the ATRF approach contrasts favourably with the support that is offered by the pharmaceutical industry, which is product-related, unrefereed, and not usually widely advertised. ${ }^{4}$ The process described by the ATRF is very different to that reported in the US, where the CTR has pursued a highly interventionist approach to stymie funded research whose findings were inimical to the tobacco industry. ${ }^{19}$ In Australia, tobacco lobbying and industry-commissioned research has been organised by the Tobacco Institute of Australia. ${ }^{20}$ It is not known whether there is any contact between the ATRF and the Tobacco Institute of Australia.

Notwithstanding the arguments advanced in favour of tobacco industry support for research, a number of groups have expressed their strong opposition to the acceptance of funds from this source including the Australian Medical Association, ${ }^{21}$ the Thoracic Society of Australia, ${ }^{22}$ the National Heart Foundation of Australia, ${ }^{23}$ and State cancer societies such as the New South Wales Cancer Council. ${ }^{24}$ The two latter organisations have introduced policies which prohibit persons currently receiving tobacco industry funds from accepting their financial support. ${ }^{23,24}$

Four main arguments have been advanced by opponents of tobacco industry support for research. Many commentators have argued that the industry receives undeserved respectability from its research sponsorship. ${ }^{1-3,5,7,11,12}$ Research funding has been viewed as a public relations vehicle designed to foster a false impression that cigarette manufacturers are interested in investigating the smoking and health "question". ${ }^{5,11}$ Cummings et al ${ }^{12}$ have argued this is a misuse of science and that "Even assuming that adequate funding is not available elsewhere, tobacco industry-supported scientists must ask themselves whether the value of their research in expanding the body of biomedical knowledge outweighs its utility in furthering the corporate interests of a business which kills 430000 Americans every year". As noted in a recent article, Addison Yeaman, ex-chairman of the CTR, has reaffirmed his 1975 assessment that "CTR is [the] best and cheapest insurance the tobacco industry can buy, and without it, the industry would have to invent CTR, or would be dead". ${ }^{19}$

A second argument concerns the extent to which support is provided to the industry position that more research is required to 
prove that smoking causes disease. Both Chap$\operatorname{man}^{5}$ and Cummings et $a l^{12}$ provide examples which suggest that medical research funding has been used by the tobacco industry as a strategy to stall government controls and to foster a climate of doubt about the health damage caused by smoking. The CTR has spent millions of dollars funding a small number of researchers whose views about tobacco were inconsistent with mainstream science. ${ }^{19}$ Armstrong et $a l^{25}$ note it may safely be predicted that the industry will persist in making every effort to ensure the highest possible sales of its lethal product.

Thirdly, critics point out that potentially influential and articulate opponents of tobacco industry activities may be less vocal because of their acceptance of industry funding ${ }^{11}$. A British Medical fournal editorial ${ }^{1}$ noted that it is impolite to "bite the hand that feeds". Researchers and universities receiving tobacco industry funds may be constrained, even without conscious realisation, in what they say publicly about the industry and smoking. There may be parallels here with the dependence of print media on cigarette advertising revenue. There is strong statistical evidence that cigarette advertising in magazines is associated with diminished coverage of the hazards of smoking. ${ }^{26}$

A fourth objection relates to the degree to which the kind of research undertaken and its reporting may be influenced, even distorted, by tobacco industry funding. ${ }^{20}$ Relman, ${ }^{27}$ when discussing the general issue of connections between industry and academic medical scientists, noted "One does not have to assume that researchers are venal to appreciate that they may be affected (consciously or unconsciously) by economic incentives, which can influence the way they design or conduct their studies, how they interpret the results, or how and when they choose to report them ". Statements from former CTR-funded scientists indicate the tobacco industry did successfully pressure researchers to modify the way results were presented. ${ }^{19}$ In addition, industry lawyers overruled decisions of the CTR scientific board and cancelled contracts when research produced unfavourable results. For example, a study which showed preliminary evidence of an increased risk of lung cancer in mice inhaling the equivalent of five cigarettes a day was cancelled. Other studies with potential adverse consequences for the tobacco industry were never published. ${ }^{19}$

One further objection focuses specifically on tobacco research in agriculture. A number of tobacco control reports have stressed the need for government support to reduce tobacco production and to assist tobacco growers to move out of the industry. ${ }^{28-30}$ However, these objectives directly conflict with those of primary industry research organisations such as the TRDC which seek to increase production by improving tobacco leaf quality and reducing costs.

Clearly, the tobacco industry's involvement in funding research remains highly controversial. Attempts to assess the attitudes of individual recipients of tobacco industry research funds have resulted in low response rates in Britain ${ }^{5}$ and the US. ${ }^{12}$ However, apart for a brief report on acceptance of tobacco industry research funding by US medical schools, ${ }^{31}$ no surveys have been reported which examined the positions adopted on this issue by the main institutions responsible for administering research funds - namely, institutions of higher education. In terms of potential impact, any decisions made at an institutional level will have more effect than the choices made by individual researchers about whether or not to apply for tobacco industry support. Therefore, the aim of this study was to investigate the current policies and practices of Australian institutions of higher education in relation to tobacco industry research funding.

\section{Methods}

Institutions of higher education in Australia were located using a print-out supplied by the Higher Education Division of the Department of Employment, Education and Training, which was cross-checked against two other sources. $^{32,33}$ In total, 45 institutions were identified.

Lists of institutions of higher education which had received research funds in 1991 and 1992 were requested from the ATRF, RF, and TRDC.

The survey of institutions of higher education consisted of eight questions. Two questions sought background information about the institution while the remainder focussed on policies and practices in relation to each source of tobacco industry research funding. Space was allotted for respondents to write comments about their institution's position on this issue.

The questionnaire was mailed with a covering letter and a reply-paid envelope to the head of each institution in April 1993. The covering letter indicated that the issue of tobacco industry support for research was a controversial area but did not adopt a value position, or mention the NSW Cancer Council funding, in an effort to reduce response bias. Institutions which did not respond to the first mailing were sent a second questionnaire approximately one month later and then received up to two reminder phone calls. The project was approved by the Human Research Ethics Committee of the University of Newcastle.

\section{Results}

\section{REPORTS OF TOBACCO RESEARCH FUNDS}

The ATRF responded with a list of all institutions of higher education funded in 1991 and 1992 (Ferguson JB, personal communication, 21 December 1993). During this period eight $(18 \%)$ of the 45 institutions had received ATRF funding. The RFED provided a public report and supplementary information which listed all their Fellowship recipients and their host institutions from 1962-93 ${ }^{17}$ (Davidson AK, personal communication, 25 August 
1993). In the period 1991-92 five Fellowships were awarded to four institutions of higher education. The TRDC forwarded its 1991-92 Annual Report, which included lists of organisations receiving TRDC research funds. ${ }^{18}$ Only one institution of higher education received funding from the TRDC in the 1991-92 financial year. That institution received $\$ 25842$

\section{SURVEY OF INSTITUTIONS OF HIGHER \\ EDUCATION}

Questionnaires were returned by 42 institutions. Two institutions reported that they had amalgamated with others on the list and that it was not appropriate for them to complete the survey. Therefore, the response rate from eligible institutions was $98 \%$. The only institution which did not respond included a medical faculty.

\section{INSTITUTION CHARACTERISTICS}

Nineteen $(45 \%)$ institutions had at least 10000 equivalent full-time students (EFTSU) enrolled. Only $10(23 \%)$ institutions had less than 5000 EFTSU. Nine (26\%) institutions reported that they offered an undergraduate programme in medicine, $25(62 \%)$ offered a nursing programme and $34(85 \%)$ offered a programme(s) in other biomedical or health areas.

POLICIES AND PRACTICES IN RELATION TO TOBACCO INDUSTRY RESEARCH FUNDING

Twelve $(29 \%)$ institutions reported that the ethics of accepting funds from tobacco industry sources had ever formally been discussed at the Senate or equivalent governing body. In seven of these institutions the most recent discussion had occurred prior to 1990 . Twenty-four institutions $(57 \%$ ) indicated that the issue had never been discussed and six $(14 \%)$ did not know whether a formal discussion had ever occurred.

The official positions of the institutions in relation to the three sources of tobacco industry research funding are summarised in table 2 . Two $(5 \%)$ of the institutions indicated they had a written policy which precluded acceptance of funds from all three tobacco industry sources. Six $(14 \%)$ had a written policy in relation to at least one funding source. One other institution had signed an agreement with a state government agency precluding acceptance of such research funds, but a formal policy was not yet in place. A higher proportion $(24 \%)$ of institutions reported they did not officially circulate any tobacco industry promotional material. Almost one-third (31\%) chose not to circulate material from at least one tobacco research body. Approximately onefifth $(21 \%)$ of the institutions did not permit their staff to accept funds from one or more industry sources. Two (5\%) of the institutions had written to the RFED stating they would have no official contact and one of these had also formally severed links with the ATRF. Five $(12 \%)$ respondents anticipated that their institution's policies in this area might be modified in the next six months. In summary, although policies were being implemented, most institutions reported that they would currently administer funds from these sources in the same way as any other external research funds.

A minority of institutions reported actually receiving funds from any of the sources in the 1991-92 financial year: eight (19\%) reported acceptance of money from the ATRF, three $(7 \%)$ from the RFED, and none from the TRDC. One institution which reported that no RFED funds were received in 1991-92 was listed as the host institution of a $1992 \mathrm{Fel}$ lowship in the RFED material. This was the only case where industry data did not agree with information supplied by the institutions. Of those institutions that returned questionnaires, only one failed to provide any response to the question about the number of staff receiving tobacco industry research funds. That institution was listed as a recipient of funds from all three sources in 1991-92. The only institution which failed to return the questionnaire was listed as the host institution of one RFED Fellowship in both 1991 and 1992. Taking into account the tobacco research reports, a total of $13(30 \%)$ institutions of higher education received funds in 1991-92 from at least one tobacco industry source.

Table 2 Percentage of Australian institutions of higher education $(n=42)$ reporting adoption of policies in relation to tobacco industry research funding

\begin{tabular}{|c|c|c|c|c|}
\hline & $\begin{array}{c}\text { Australian } \\
\text { Tobacco } \\
\text { Research } \\
\text { Foundation }(\%)\end{array}$ & $\begin{array}{l}\text { Rothmans } \\
\text { Foundation } \\
\text { Education } \\
\text { Division }(\%)\end{array}$ & $\begin{array}{l}\text { Tobacco } \\
\text { Research and } \\
\text { Development } \\
\text { Council }(\%)\end{array}$ & $\begin{array}{c}\text { Overall } \\
\text { percentage }\end{array}$ \\
\hline $\begin{array}{l}\text { Institution has } \\
\text { specific written } \\
\text { policy on this } \\
\text { source of funding }\end{array}$ & 9 & 14 & 9 & 14 \\
\hline $\begin{array}{l}\text { Funding notifications } \\
\text { are not circulated }\end{array}$ & 26 & 29 & 24 & 31 \\
\hline $\begin{array}{l}\text { Staff members may } \\
\text { not accept funds }\end{array}$ & 17 & 21 & 17 & 21 \\
\hline $\begin{array}{l}\text { Institution has } \\
\text { written to funding } \\
\text { source indicating it } \\
\text { will have no official } \\
\text { contact }\end{array}$ & 2 & 5 & 0 & 5 \\
\hline
\end{tabular}

* Pertaining to at least one of the three tobacco industry funding sources. 
Only one of the nine institutions which included a medical faculty had an institutionwide written policy precluding acceptance of all tobacco industry research funds. However, three other institutions in this group reported policies (two written, one unwritten) that applied only to the RFED and one had an unwritten policy which applied to both the RFED and the ATRF. Based on the institutions' questionnaires and the tobacco industry research reports, eight of the 10 institutions in Australia which include medical faculties had received research funding from tobacco industry sources in 1991-92. Institutions with medical faculties were significantly more likely ( $p<0.001$, Fisher's Exact test) to have received such funding than institutions without medical faculties. In addition to the medical faculties in institutions with policies, four other medical faculties have adopted facultyspecific policies ruling out dealings with tobacco industry research groups. In total, seven medical faculties have decided that tobacco industry grants will not be processed by faculty committees.

Many respondents (27) provided written comments. Twelve respondents from institutions without policies noted that research funds from the tobacco industry either had never been sought or had not been sought for several years. Several argued that the absence of an official policy reflected the lack of any applications for tobacco industry research support. However, even amongst the institutions which had received research funds from tobacco industry sources in 1991-92, only a minority of respondents (five) were aware that formal discussions had ever occurred about the ethics of accepting such funds.

One respondent indicated that, although the institution had no policy on research funds, its strong position on other aspects of tobacco prevention made it extremely unlikely that funds would be sought from the tobacco industry. Another respondent noted that funds would not be accepted from the tobacco industry, if this were likely to bring the institution into disrepute. In another institution with no written policy, the respondent reported that the Office of Research had advised the Vice Chancellor not to accept research funds from the tobacco industry and that the availability of such funding was not advertised. However, this was the same institution whose questionnaire response did not agree with the RFED list. In one institution without an official policy, material promoting tobacco industry research funds was circulated at two of its campuses but not at a third. Intense discussion about a wider policy was reportedly occurring at one institution where only the Faculty of Medicine currently had a policy precluding applications for tobacco industry funds. Three Western Australian respondents stressed that their institutions had signed agreements with state authorities which prevented their acceptance of tobacco industry monies. Since the survey, a fourth Western Australian institution has signed a similar agreement. One of these institutions had declined a RFED Fellowship in 1992 and a second was about to write to the RFED informing it of the new policy. Five respondents noted that the issue of accepting research funds from the tobacco industry would be referred to relevant institutional bodies for official discussion as a result of the survey drawing attention to the subject. Nearly all the institutions (38) indicated that they would like to receive the results of the survey.

\section{Discussion}

Tobacco industry sponsorship of sports has received extensive coverage in the lay press. ${ }^{34-36}$ There is strong public support for a ban on sports sponsorships by tobacco companies. ${ }^{34}$ In contrast, the issue of tobacco industry sponsorship of research has received minimal coverage outside medical journals. This representative survey makes it clear that, even amongst institutions of higher education, the issue has received little attention. Less than a third $(29 \%)$ of the institutions reported that formal discussions had ever occurred about the ethical issues involved in accepting tobacco industry research funds. Further, only $38 \%$ of respondents from institutions which had actually received such funds in 1991-92, could recall formal discussions ever taking place. Few institutions had policies designed to preclude acceptance of tobacco industry research funds or to prevent circulation of material advertising its availability. Institutions with medical faculties, the group which might have been expected to be at the forefront of opposition to industry funding, were significantly more likely to have accepted research money from these sources in recent years. However, it should be noted that institutions with medical faculties tend to be larger and more research-orientated. Further, the majority of the medical faculties, in contrast to their host institutions, were opposed to tobacco industry funding.

The vast majority $(87 \%)$ of institutions without written policies banning the three sources of tobacco industry research funding did not anticipate their positions would change in the medium term. Therefore, health advocacy groups need to consider what can be done to alter the status quo. Based on experience in other sponsorship areas, ${ }^{37}$ it is clear that the tobacco industry will fight hard to maintain its involvement in a highly respectable area such as research funding. It is likely that a combination of strategies will be necessary to eliminate the tobacco industry's ties with institutions of higher education.

The first and most straightforward strategy involves direct requests to institutions by agencies involved in tobacco control asking them to place this issue on the agenda of their governing bodies with a recommendation that they cease accepting tobacco industry funds. Even a passive approach such as this survey appeared to have an intervention effect in several institutions, at least in terms of putting the ethics of tobacco industry research spon- 
sorship on their agendas. Institutions would be encouraged to consider the issue seriously, if a number of prominent, mainstream pro-health bodies collaborated to present a combined request. Such a request should be supported by a strongly argued position paper. Potential allies on the institutions' decision-making committees could be identified and their support sought. However, there is certainly no guarantee that in-house discussions will lead in the short term to a rejection of tobacco industry research funding. For example, protracted and, at times, heated discussions at the University of Newcastle's Academic Senate and Research Management Committee during 1993 resulted in the University rejecting a ban on tobacco industry research funds proposed by the Faculty of Medicine. However, the University did opt to endorse a policy which merely encouraged " ... each of its members to carefully consider the arguments for not accepting tobacco industry support" ${ }^{38}$ This policy shift may represent a useful intermediate step in attempts to sever ties with the tobacco industry. Central to the argument against the ban was the notion of academic freedom - namely, that the University's fundamental mission was to promote open and critical inquiry. ${ }^{39}$ It was argued that a policy of prohibiting tobacco industry research funds aligned the University to a particular set of social goals, set a dangerous precedent, and involved a loss of autonomy.

Similar sentiments have recently been expressed by the Research Committee Chairman at the University of Western Australia, where the university currently has in force a ban on tobacco industry funds as a condition of receiving research money from the State Government agency, Healthway. ${ }^{40}$ Nonetheless, in April 1994, the Senate of the University of Western Australia passed a resolution that the University dissociate itself from the tobacco industry (Barber $\mathrm{MN}$, personal communication, 10 May 1994). Subsequently, the Vice-Chancellor has approved guidelines directing that funding from the ATRF, RFED and TRDC will not be accepted for any purpose.

One impediment to a ban on tobacco industry research funding may be the diversification of tobacco-controlled companies into many other non-tobacco business activities. A proposed ban is likely to have a higher chance of acceptance if it targets business units whose primary activity involves the production, sale, or marketing of tobacco products. The University of Western Australia's approach to this dilemma has been to allow the ViceChancellor discretion to accept funds from tobacco-controlled business units whose primary function is unrelated to tobacco products and where acceptance cannot be construed to support the tobacco industry or its lobby.

Clearly, opponents of tobacco industry involvement in research must develop arguments, acceptable to an academic audience, which counter the view that the decision to accept or reject such funds is a matter for the individual conscience. Elaboration of the
World Health Organisation (WHO) Expert Committee response to the notion that smoking control activity is an infringement of essential human freedom could be helpful in this regard: "Freedom should be seen not as the freedom of the manufacturer to promote a known health hazard but rather as the freedom and ability of society to implement public health measures". ${ }^{41}$

A second strategy to encourage institutions to cease acceptance of tobacco industry money requires focusing public attention on the credibility of recipients. Institutions of higher education and individual researchers are influenced by public opinion. Ernster ${ }^{42}$ has recommended that public protests should be mounted against tobacco company sponsorships including funding of educational and medical programmes. Pro-health groups could target those institutions currently receiving tobacco industry funds, pointing out that such sponsorship is only possible because of the profits that have come at the expense of approximately 18110 deaths due to tobacco each year in Australia. ${ }^{43}$ Institutions with medical faculties, the major funding recipients, may be more sensitive to publicity about the ethics of training future doctors and receiving tobacco industry money at the same time. However, $85 \%$ of all the institutions in this survey reported offering courses in biomedical or health areas. It may be that pro-health groups will experience difficulty in identifying those institutions receiving tobacco industry funds. In this regard, it is interesting to note that the two institutions which failed to provide data on this issue were both funding recipients and that a third institution provided information that was inconsistent with the RFED report. Pro-health groups may need to use a variety of techniques to obtain full and accurate data including "Freedom of Information" requests.

Another strategy would be to focus on the publication end of research. Scientific journals could be lobbied to reject work supported by tobacco industry sources. The Medical fournal of Australia has stated that it will "... examine most critically any work that is submitted for publication which has been supported by the Australian Tobacco Research Foundation". Whether this policy has resulted in any manuscripts being rejected is not known. This strategy may not be acceptable because of the perceived erosion of freedom of speech, which is an anathema in the scientific community. The recent report of the WHO Expert Committee on Drug Dependence ${ }^{44}$ merely recommends that editors of scientific journals should require authors receiving alcohol, tobacco or pharmaceutical industry sponsorship to follow specific guidelines for disclosing their sources of funding. Consistent with this position, we would argue that industry funding sources should be disclosed in any article or letter to the editor from authors receiving industry support. The WHO Expert Committee's recommendation provides no support for a publication ban.

A weakness in these first three strategies is 
that they require institutions of higher education or scientific journals to take voluntary action. Previous experience in other areas of tobacco control indicates that self-regulation is ineffective. ${ }^{45} \mathrm{~A}$ fourth strategy would involve legislative action to ban tobacco industry sponsorship of research. A ban could be accompanied by the provision of replacement funding. No Australian government has yet taken this step and it may be naive to expect that specific legislation would ever be introduced or adopted in this area. The National Health Policy on Tobacco ${ }^{46}$ does list as one of its strategies the phasing out of tobacco industry sponsorship of sporting, cultural, and educational activities. The RFED could be affected by this strategy; however, there is no indication of how long the phasing-out period will be. Significantly, sponsorship of research activities is not even mentioned.

A more feasible step which governments could take, rather than banning tobacco industry funding, would be to establish alternative sources of funding for which institutions in receipt of tobacco money would be ineligible to apply. This appears to be an effective strategy, since all four Western Australian public institutions have signed contracts with Healthway, the Western Australian Health Promotion Foundation which require their institutions not to accept monies from the tobacco industry. Healthway was established in 1991 by the Tobacco Control Act to make cigarettes less attractive to adolescents and to phase out tobacco industry sponsorships. ${ }^{47}$ Total revenue was $\$ 11303260$ in 1991-92 and $\$ 13168193$ in 1992-93. Funds are derived from tobacco excise tax revenue and are used to sponsor sports and arts organisations as well as to support health bodies. In the 1991-92 financial year, Healthway allocated $\$ 1342798$ for health promotion research in Western Australia. ${ }^{47}$ This dwarfs the national allocation for research at institutions of higher education from tobacco industry sources, which was approximately $\$ 695000$ in 1992 . South Australia, Victoria, and the Australian Capital Territory also have health promotion foundations funded by tobacco excise taxes, but these foundations have not secured binding agreements with institutions of higher education preventing acceptance of tobacco industry funds. The recent debate at the University of Western Australia which eventually led to the rejection of tobacco industry funds suggests that this strategy will be resisted by some academics. ${ }^{40}$ Non-government health agencies which fund research could support such an approach by attempting to negotiate similar agreements with institutions of higher education. Support from the National Health and Medical Research Council would be a powerful incentive for institutional change.

In relation to the TRDC, campaigning should concentrate on the Commonwealth Government rather than the tobacco industry or the educational institutions, since it is a government-administered body. Pro-health groups should immediately push to have TRDC grants removed from the National
Grants Competitive Index. ${ }^{48}$ Unlike the ATRF and RFED, the TRDC funds are currently included in the performance indicators formula, which influences a small portion of government funding for institutions. Given the tiny level of TRDC funds received by only one institution, this would be a symbolic gesture rather than one with a major practical effect. More importantly, there should be a campaign to wind up the TRDC or to redirect its activities entirely into research concerned with tobacco crop substitution.

\section{Conclusion}

One of the objectives of the anti-smoking movement is to isolate the tobacco industry by fighting it on all fronts. ${ }^{49,50}$ For this reason, breaking the industry's nexus with institutions of higher education, provided by its sponsorship of research, represents an important tobacco control objective. The investment of approximately $\$ 695000$ (1992 total) on tobacco research in institutions of higher education must appear to the industry a highly costeffective method of shoring up its respectability, given tobacco companies spent approximately $\$ 32$ million on advertising in the main Australian media during $1987 . .^{51} \mathrm{Re}-$ search sponsorship allies the tobacco industry with a highly prestigious group. As in other areas of tobacco control, attempts to break this alliance will be strongly resisted by the industry, its supporting researchers, and some recipient institutions. Although useful progress has been made in this area, much remains to be done. Prior to this survey, only a minority of institutions had ever formally considered the ethical problems raised by acceptance of tobacco industry research funds and fewer still had written policies about non-acceptance. Even institutions which do not currently accept tobacco industry research funds can be viewed as providing tacit support for such sponsorship if they distribute industry promotional material or keep the option of future acceptance open. Encouragingly, more institutions without formal policies choose not to circulate tobacco industry material and most medical faculties refuse to administer tobacco industry funds. Action will probably be required on a number of fronts within and outside institutions of higher education by medical associations, health societies, and government to eliminate the demand for tobacco industry research funds and to prohibit the supply of such funds.

\section{Addendum}

During the period this manuscript was in press, an advertisement appeared in newspapers around Australia indicating that the ATRF had changed its name to the Smoking and Health Research Foundation. Newspaper reports also noted that the Rothmans Foundation including the RFED would cease operation on 30 June 1994. The chairman of Rothmans, Mr John Utz, said “ ... anti-tobacco legislation has become so extensive that it 
was making it more and more difficult for the foundation to operate." (McNicoll DD. Tobacco firm scraps sport and culture arm. The Australian 1994; 17 June: 3.).

Thanks to Julie-Anne Kenworthy for assistance with data collection. This research was undertaken by the NSW Cancer Council Cancer Education Research Project team, directed by Professor R Sanson-Fisher. The views expressed are not necessarily those of the Cancer Council.

1 Anonymous. Taking money from the devil (Editorial). BMF 1985; 291: 1743-4.

2 Pierce JP. Tobacco sponsorship of medical research. Med $\mathcal{F}$ Aust 1986; 145: 658 .

3 Shaw J. He who sups with the devil ... (Editorial). Med $\mathcal{F}$ Aust 1986; 144: 617 .

4 Castaldi PA. On supping with the devil. Med f Aust $1986 ; 145: 360$

5 Chapman $S$. Tobacco industry health research 'blood money': the British Health Promotion Research Trust. Community Health Stud 1987; XI: 139-42.

6 Doyle AE, Rand M, Powell LW, Simmonds W, Wing L, Zylstra W. The Australian Tobacco Research Foundation. Med $f$ Aust 1988; 148 : 152.

7 Chapman S, Brown R, Daube M, McMichael AJ, Woodward S. The Australian Tobacco Research Foundation. Med $\mathcal{f}$ Aust 1988; 149: 46,49.

8 Donovan J. The Australian Tobacco Research Foundation. Med $¥$ A ust 1988; 148: 320 .

9 Musk AW. The Australian Tobacco Research Foundation Med $\mathcal{F}$ Aust 1988; 148: 544

10 Castleden WM. The Australian Tobacco Research Foundation. Med f Aust 1988; 149: 394.

11 Warner KE. Tobacco industry scientific advisors: serving society or selling cigarettes? Am $f$ Public Health $1991 ; 81$ : 839-42.

12 Cummings KM, Sciandra R, Gingrass A, Davis R. What scientists funded by the tobacco industry believe about the hazards of cigarette smoking. Am $\mathcal{F}$ Public Health $1991 ; 81: 894-6$.

13 Spitzer WO, Lawrence V, Dales R, et al. Links between passive smoking and disease: a best-evidence synthesis. A Report of the Working Grou

14 Peacock JL, Bland M, Anderson HR. Effects on birthweight of alcohol and caffeine consumption in smoking women. f Epidemiol Community Health 1991 ; 45: 159-63.

15 Seller MJ, Bnait KS, Cairns NJ. Effects of maternal tobacco smoke inhalation on early embryonic growth. In: Poswillo D, Alberman E, eds. Effects of smoking on the fetus, neonate and child. Oxford: Oxford University Press, 1992; pp 45-59.

16 Australian Tobacco Research Foundation. Information for applicants concerning research grants and post-graduate scholarships, 1992. Rose Bay, May 1992.

17 Rothmans Foundation Fellowships. Thirtieth Anniversary 1960-1990. Sydney: Rothmans Foundation Education Division, undated.

18 Tobacco Research and Development Council. Annual Report 1991-92. Dickson: Tobacco Research and Development Council, 1992

19 Freedman AM, Cohen LP. Smoke and mirrors. How cigarette makers keep health question 'open' year after year. Council for Tobacco Research is billed as independent but guided by lawyers. An industry insurance policy. Wall Street $\mathcal{f}$ 1993; 11 February: 37-42.

20 Winstanley M. Tobacco in Australia. Facts and issues. Surry Hills: ASH, 1989; pp102-3

21 Policies of the Australian Medical Association and Directory for 1987- 88. Glebe: Australian Medical Association, undated, 51 .

22 Musk AW, Lindsay D. Smoking control policy. Med f Aust $1988 ; 144: 28-9$. 23 Magnus P. Tobacco sponsorship. Woden: National Heart
Foundation of Australia Memorandum, 1993.

24 The Cancer Council Research Project Grants. General Information to Applicants. Woolloomooloo: The Cancer Council, 1993.

25 Armstrong BK, Daube ME, Shean RE. A smoke-free Australia - our bicentenary resolution? Med $\mathcal{f}$ Aust 1988; 149: 1-2.

26 Warner KE, Goldenhar LM, McLaughlin CG. Cigarette advertising and magazine coverage of the hazards of smoking. A statistical analysis. N Engl f Med 1992; 326: 305-9.

27 Relman AS. Dealing with conflicts of interest. $N$ Engl f Med 1984; 310: 1182-3.

28 Nakajima $H$. Coalitions can overcome tobacco industry power. World Smoking Health 1992; 17: 6-7.

29 Anonymous. The politics of health promotion. Health Promotion 1992; 31: 16-7.

30 National cancer prevention policy 1993. Woolloomooloo: Australian Cancer Society, 1993; pp 9-25.

31 Blum A. Ethics of tobacco-funded research in US medical schools. Tobacco Control 1992; 1: 244-5.

32 Dwyer M, Lewis S. Universities in Australia. The Complete Students Guide. 2nd edn. Sydney: Financial Review Library, 1992.

33 Ashenden D, Milligan S. Good universities guide to Australian universities. Port Melbourne: Mandarin, 1992.

34 Cummings F. Survey: ban all tobacco advertising. Canberra Times 1989; 27 March: 1 .

35 Bisset $\mathrm{K}$. How Hunter children are influenced to smoke by sport sponsors. The Newcastle Herald 1992; 9 April: 1,3.

36 Anonymous. Doctors gear up for fight against tobacco ads at Vic grand prix. The Newcastle Herald 1993; 6

37 Taylor $\mathrm{P}$. The smoke ring: tobacco, money and multinational politics. London: Sphere Books, 1984; pp 114-27.

38 Farley PH. Tobacco research funds. Report from Research Management Committee. The University of Newcastle Academic Senate. Extract from document Ac S115: 93, 28 July 1993

39 Hooker CA. Tobacco sponsorship, ethics and institutional responsibility. The University of Newcastle document Ac S95: 93,22 June 1993.

40 Kovacs $Z$. Academics split over ban on tobacco cash. The West Australian 1993; 4 August: 15.

41 Report of a WHO Expert Committee. Smoking control. Geneva: World Health Organisation, 1979; Technical Report Series 636.

42 Ernster VL. Women, smoking, cigarette advertising and cancer. Women and Health 1986; 11:217-35.

43 Department of Health, Housing and Community Services. Statistics on drug abuse in Australia 1992. Canberra: Australian Government Publishing Service, 1992; 26.

44 WHO Expert Committee on Drug Dependence. Twentyeighth report. Geneva : World Health Organisation, 1993; Technical Report Series 836.

45 Report of a WHO Expert Committee. Smoking control strategies in developing countries. Geneva: World Health Organisation, 1983; Technical Report Series 695.

46 National Campaign Against Drug Abuse. National health policy on tobacco in Australia and examples of strategies for implementation. Canberra: Commonwealth of Australia, 1991.

47 Western Australian Health Promotion Foundation. Annual Report 1992-93 Healthway. West Perth: Western Australian Health Promotion Foundation, 1993.

48 Australian Vice Chancellors' Committee. Instructions for 1994 financial and publications research data collection. Canberra: Australian Vice Chancellors' Committee, March, 1994.

49 Chesterfield-Evans A. Staging a campaign against tobacco. In: Durston B, Jamrozik K, eds. Tobacco and health 1990. The global war. Proceedings of the Seventh World Conference on Tobacco and Health. Perth: Health Department of Western Australia, 1990; pp 809-11.

50 Daynard RA. Health advocates v. tobacco industry: playing for high stakes. World Smoking Health 1992; $17: 2$.

51 Department of Community Services and Health. Tobacco in Australia. A summary of related statistics. Canberra: Australian Government Publishing Service, 1990; p 59. 